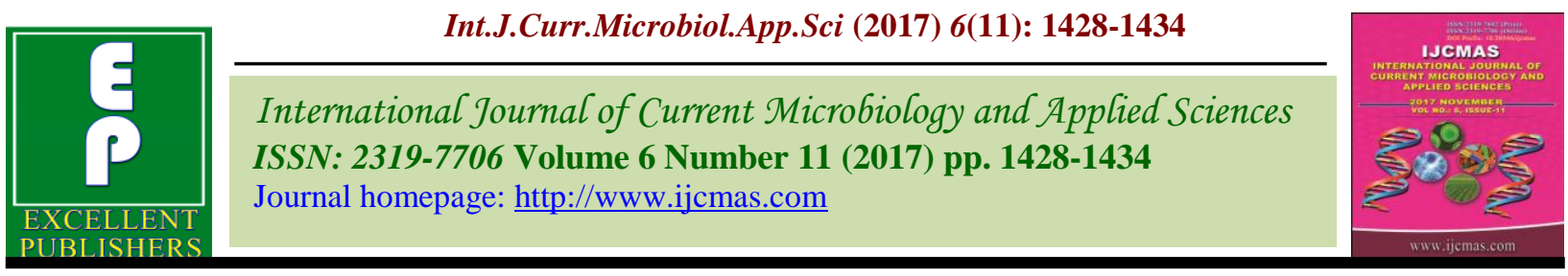

Original Research Article

https://doi.org/10.20546/ijcmas.2017.611.170

\title{
Study of Hundred Years Rainfall Distribution Pattern for Crop Planning in Bidar Region (Karnataka), India
}

\author{
S. Ravi ${ }^{1}$, S.N. Bhat ${ }^{1}$, Kamble Anand Shankar ${ }^{2 *}$ and Vishswanath Biradar ${ }^{2}$ \\ ${ }^{1}$ Deaprtment of Soil Science and Agricultural Chemistry, \\ ${ }^{2}$ Department of Agronomy, ICAR-KVK, Bidar, UAS, Raichur, Karnataka, India \\ *Corresponding author
}

A B S T R A C T

Daily rainfall data of one hundred fifteen years (1901-2015) have been analyzed for establishing the long term averages of nakshatra-wise, monthly, seasonal and annual

Keywords

Seasonal rainfall,

Rainy days and

nakshatra-wise

rainfall.

Article Info

Accepted:

12 September 2017

Available Online:

10 November 2017 rainfall and its variability. The overall mean annual rainfall at Bidar region was $930.4 \mathrm{~mm}$ and distribution of $730.2 \mathrm{~mm}, 113.8 \mathrm{~mm}, 72.8 \mathrm{~mm}$ and $21.1 \mathrm{~mm}$ in monsoon, post monsoon, summer and winter respectively. The coefficient of variation of 26.6 indicated that rainfall was more or less stable over the years. July month receives maximum mean rainfall of $206.6 \mathrm{~mm}$ and contributed 22.2 per cent followed by September $(201.4 \mathrm{~mm}$, contributed 21.6 per cent). There is an ample scope for rain water harvesting from July to September which can be utilized as crop saving irrigation as well as pre sowing irrigation for succeeding Rabi crops which are generally sown on residual soil moisture. According to 'Nakshatras', the traditional system of rainfall distribution for agriculture, revealed that the period from Punarvasu to Swati which covers the monsoon and post monsoon period received good amount of rainfall during which crops like Sugarcane, Maize, Bajra and pulses like Greengram, Blackgram, Soybean, Redgram can be taken up during monsoon and chick pea, Rabi sorghum, safflower can be taken up during post monsoon.

\section{Introduction}

Agriculture, especially in developing countries, is a sector which is vulnerable to risks of various types. Most importantly, weather related risks play a major role in affecting agricultural income. These would include extreme rainfall events which result in floods/droughts, as well as extreme temperature events. Poor and small farmers are especially susceptible to income variability because of weather - related risks to their crops. Rainfall, being considered as the prime input for agriculture has its own erratic behavior in terms of amount and distribution. For better crop planning, a detailed study on rainfall behaviour is vital. Rainfall variability, both in time and space influences the agricultural productivity and sustainability of a region, as opined by Virmani (1994). Bidar region of Karnataka state is predominantly a rainfed region. South west monsoon is the predominant monsoon in the region and pigeon pea and sugarcane cropping system prevails. The agricultural crop productivity largely depends on the rainfall distribution and its intensity during the rainy season. Rainfall analysis for crop planning was carried out in different regions of the country as reported by Chaudhury and 
Tomar (1999); Sastri et al., (1999) Sarma et al., (1996); Tiwari et al., (1992) and Sahoo et al., (1991). In this context, an attempt was made at Krishi Vigyan Kendra, Bidar, to analyze the rainfall variability in monthly, seasonally and annually for Bidar region.

Agricultural production in India mainly depends upon the occurrence of rainfall during the cropping season. The timely onset, its distribution and sufficient monsoon rainfall is the key for better agricultural production in any part of the country which directly influences rural poverty situation (Varshneya et al., 2011). There is considerable traditional knowledge of variability of rainfall patterns, since rainfed cultivation has been carried out for several centuries in India. The periods used by the farmers are however, not weeks or months but so-called "Nakshatras" which are 13 or 14 day periods based on solar calendar. The Nakshatras are constellations through which the sun passes in a year. There are 27 Nakshatras in a year viz., Purvashada, Uttarabadrapada, Shravana, Danista, Purvabhadra, Uttarabhadra, Revathi, Ashwini, Bharini, Krutika, Rohini, Mrugashira, Aridhra, Punarvasu, Pushya, Aslesha, Makha, Pubba, Uttara, Hastha, Chitta, Swathi, Vishaka, Anuradha, Jyeshta and Moola Nakshatras. Of these, the periods from Rohini to Chitta Nakshatras cover the monsoon season. The Nakshatra commences when the sun enters the specific constellation. Thus, the knowledge of the variability in these time units rather than weeks or months is considered important by the traditional farmers in Karnataka and other neighbouring States. The appropriate time for farming operations can also be worked out in terms of these time periods (Subash et al., 2011). In order to translate the meteorological events into farmer's terminology, it is necessary to perform rainfall analysis in Nakshatra periods. De et al., (2004) performed a time series analysis of rainfall on different
Nakshatra periods covering Indian monsoon season. Bavadekar et al., (2008) carried out Nakshatra-wise rainfall analysis for drought prone areas of Maharashtra. Chabbra and Haris (2014) compiled the indigenous knowledge related to climatic parameters, their forecasting during different time periods of a year (Nakshatras) based on experiences of the farmers and comparing indigenous knowledge with modern scientific analysis of weather data and their relationship with wheat and rabi maize yield in Patna, Bihar.

\section{Materials and Methods}

The daily rainfall data from Agrometeorological Centre, Agricultural Research Station, Bidar for 115 years from 1901 to 2015 was used to analyze Nakshatra-wise rainfall distribution for Bidar region. Of the 27 Nakshatras, 12 Nakshatras from Rohini (May 25 to June 7) to Swati (October 24 to November 5) were considered for the analysis. The mean, standard deviation, coefficient of variation (CV\%), minimum and maximum for Nakshatra-wise rainfall were calculated. The rainfall data were critically examined for annual, seasonal and monthly values following the procedure of Panse and Sukhatme (1985). The standard deviation (SD) and coefficient of variance (CV) of rainfall were worked out for the above periods.

\section{Results and Discussion}

\section{Annual rainfall}

The overall mean total annual rainfall of Bidar region for the past one hundred fifteen years (1901-2015) was $930.4 \mathrm{~mm}$. The lowest and highest annual rainfall recorded was $417.6 \mathrm{~mm}$ and $1688.3 \mathrm{~mm}$ respectively. The standard deviation and coefficient of variation for annual rainfall was $247.3 \mathrm{~mm}$ and 26.6 per cent (Table 2). 


\section{Seasonal rainfall}

The average seasonal rainfall and its variability during the seasons are presented in (Table 2 and Fig. 2). South west (SW) monsoon season contributes 78.5 per cent of mean annual rainfall. Rainfall during this period varied between $335.9 \mathrm{~mm}$ to 1522.4 $\mathrm{mm}$ with mean value of $730.0 \mathrm{~mm}$. Total amount of rainfall received during north east (NE) monsoon was 12.2 per cent of the mean annual rainfall.

The mean rainfall during this period was $113.8 \mathrm{~mm}$. Pre monsoon season (March May) contributed 7.8 per cent $(72.8 \mathrm{~mm})$ of the mean annual rainfall. The winter rainfall contributed just than 1.5 per cent $(13.9 \mathrm{~mm})$ to the mean annual rainfall. The quantum of rainfall received during south west monsoon appears to be sufficient to raise a successful crop, however $\mathrm{CV}$ exceeds $30 \%$ indicate risk in crop production because of low dependability.

However, on black soils, soybean, greengram, blackgram, redgram, sugarcane or cotton can be taken up with less risk when compared to red laterite soils which are low in water holding capacity. The $\mathrm{CV}$ is high during post moonsoon $(87.4 \%)$ the rabi crops like sorghum, bengalgram, safflower can be successful with one or two crop saving irrigation.

\section{Monthly rainfall}

Rainfall quantum and distribution during different months was shown in Figure 1. It is evident that monthly rainfall had bimodal peak. July month receives maximum mean rainfall of $206.6 \mathrm{~mm}$ followed by September $(201.4 \mathrm{~mm})$. The highest rainfall of $666.7 \mathrm{~mm}$ was reported in the July month followed by
October $601.4 \mathrm{~mm}$. The lowest coefficient of variation is confined to monsoon season indicating the dependability and reliability of rainfall during monsoon season (Table 1 and Fig. 1). Monthly CV is, however higher and sowing operations can commence only from last week of June to first fortnight of July.

Nevertheless, onset of monsoon of late is often delayed and is becoming more undependable. Hence, climate smart crops i.e. crops less sensitive to time of sowing like redgram, little millet, castor or desi cotton etc. could be preferred under unexpected delays.

\section{Characterization of nakshatra-wise rainfall}

Twelve nakshatras were considered for analysis because this period coincides with the crop growing period of both kharif and rabi seasons. Maximum rainfall occurred in Pushya $(106.9 \mathrm{~mm})$ followed by Uttara $(98.2$ $\mathrm{mm}$ ) (Table 3 and Fig. 3). Rainfall was received in all nakshatras and good amount of rainfall was received from Aridhra (22 June to 5 July) to Hasta (27 September to 10 October). Rainfall was lowest $(16.8 \mathrm{~mm})$ in Swati. The CV of rainfall was lowest in both in Aridhra and Uttara (71.3\% and $72.8 \%$ respectively) while it was highest (196.1\%) in Chitta. Rainfall in Aridhra and Uttara are more assured than in other nakshatras while it is the least assured in Swati and Chitta nakshatras. As indicated earlier sowing can commence from Mrigashira or Aridhra depending on soaking rains during Kharif.

The highest rainfall during Nakshatra periods are presented in Table 3 . The rainfall during Nakshatra periods ranged from $118.6 \mathrm{~mm}$ to $601.4 \mathrm{~mm}$. Chitta Nakshatra received the highest rainfall of $601.4 \mathrm{~mm}$ during 1962 followed by Pushya Nakshatra of $556.4 \mathrm{~mm}$ during 1970. The lowest rainfall of $118.6 \mathrm{~mm}$ was recorded for Rohini during 1943. 
Table.1 Monthly mean, highest and lowest rainfall along with SD and CV as observed at Bidar (1901-2015)

\begin{tabular}{|l|c|c|c|c|c|c|}
\hline \multicolumn{1}{|c|}{ Month } & $\begin{array}{c}\text { Lowest } \\
(\mathbf{m m})\end{array}$ & $\begin{array}{c}\text { Highest } \\
(\mathbf{m m})\end{array}$ & $\begin{array}{c}\text { Mean } \\
(\mathbf{m m})\end{array}$ & $\begin{array}{c}\text { SD } \\
\mathbf{m m} / \mathbf{d a y s}\end{array}$ & $\begin{array}{c}\text { CV } \\
(\boldsymbol{\%})\end{array}$ & \% of annual \\
\hline January & 0.0 & 77.4 & 6.5 & 15.3 & 237.4 & 0.7 \\
\hline February & 0.0 & 70.3 & 7.4 & 15.2 & 205.2 & 0.8 \\
\hline March & 0.0 & 121.5 & 15.1 & 24.8 & 164.7 & 1.6 \\
\hline April & 0.0 & 188.7 & 27.0 & 28.8 & 106.4 & 2.9 \\
\hline May & 0.0 & 294.9 & 30.6 & 40.7 & 132.8 & 3.3 \\
\hline June & 0.0 & 371.8 & 135.9 & 74.6 & 54.9 & 14.6 \\
\hline July & 25.0 & 666.7 & 206.6 & 117.0 & 56.7 & 22.2 \\
\hline August & 0.0 & 496.0 & 186.1 & 109.6 & 58.9 & 20.0 \\
\hline September & 29.2 & 525.0 & 201.4 & 107.9 & 53.6 & 21.6 \\
\hline October & 0.0 & 601.4 & 84.1 & 90.8 & 108.1 & 9.0 \\
\hline November & 0.0 & 300.3 & 24.3 & 43.4 & 178.9 & 2.6 \\
\hline December & 0.0 & 89.7 & 5.5 & 13.3 & 242.2 & 0.6 \\
\hline
\end{tabular}

Table.2 Characteristics of annual and seasonal rainfall as observed at Bidar (1901-2015)

\begin{tabular}{|l|c|c|c|c|c|c|}
\hline \multicolumn{1}{|c|}{$\begin{array}{c}\text { Year / } \\
\text { Seasons }\end{array}$} & $\begin{array}{c}\text { Lowest } \\
(\mathbf{m m})\end{array}$ & $\begin{array}{c}\text { Highest } \\
(\mathbf{m m})\end{array}$ & $\begin{array}{c}\text { Mean } \\
(\mathbf{m m})\end{array}$ & $\begin{array}{c}\text { SD } \\
\mathbf{m m} / \mathbf{d a y s}\end{array}$ & $\begin{array}{c}\text { CV } \\
(\boldsymbol{\%})\end{array}$ & $\begin{array}{c}\text { \% of annual } \\
\text { rainfall }\end{array}$ \\
\hline Annual & 417.6 & 1688.3 & 930.4 & 247.3 & 26.6 & 100.0 \\
\hline Winter & 0.0 & 81.0 & 13.9 & 21.1 & 152.0 & 1.5 \\
\hline Summer / Pre-monsoon & 0.0 & 294.9 & 72.8 & 53.7 & 73.8 & 7.8 \\
\hline Monsoon & 335.9 & 1522.4 & 730.0 & 220.8 & 30.2 & 78.5 \\
\hline Post monsoon & 0.0 & 629.1 & 113.8 & 99.4 & 87.4 & 12.2 \\
\hline
\end{tabular}

Annual : January - December Winter : January - February Summer : March- May Monsoon : June - September Post monsoon: October - December

SD : Standard Deviation CV : Coefficient of variation

Table.3 Statistical characteristics of nakshatra-wise rainfall in Bidar

\begin{tabular}{|c|c|c|c|c|c|c|c|}
\hline \multirow[b]{2}{*}{ Season } & \multirow[b]{2}{*}{ Nakshatra } & \multirow[b]{2}{*}{ Period } & \multicolumn{3}{|c|}{ Rainfall } & \multicolumn{2}{|c|}{ Highest rainfall } \\
\hline & & & $\begin{array}{l}\text { Mean } \\
(\mathbf{m m})\end{array}$ & $\begin{array}{c}\text { SD } \\
(\mathbf{m m})\end{array}$ & $\begin{array}{l}\text { CV } \\
(\%)\end{array}$ & $\begin{array}{c}\text { Amount } \\
(\mathbf{m m})\end{array}$ & Year \\
\hline \multirow[t]{2}{*}{ Pre-monsoon } & Rohini & May 25-Jun.7 & 27.7 & 27.9 & 100.7 & 118.6 & 1943 \\
\hline & Mrigashira & Jun.8-Jun.21 & 65.5 & 55.5 & 84.8 & 272.2 & 1953 \\
\hline \multirow[t]{7}{*}{ Monsoon } & Aridhra & Jun.22-Jul.5 & 78.9 & 56.2 & 71.3 & 228.6 & 1960 \\
\hline & Punarvasu & Jul.6-Jul.19 & 86.4 & 65.1 & 75.3 & 340.2 & 1989 \\
\hline & Pushya & Jul.20-Aug.2 & 106.9 & 95.7 & 89.6 & 556.4 & 1970 \\
\hline & Ashlesha & Aug.3-Aug.16 & 77.3 & 62.4 & 80.7 & 251.3 & 1907 \\
\hline & Magha & Aug.17-Aug.30 & 88.4 & 81.9 & 92.6 & 331.6 & 2003 \\
\hline & Purva & Aug.31-Sept.12 & 91.3 & 78.8 & 86.3 & 377.9 & 2008 \\
\hline & Uttara & Sept.13-Sept.26 & 98.2 & 71.5 & 72.8 & 315.0 & 1910 \\
\hline \multirow[t]{3}{*}{ Post-monsoon } & Hasta & Sept.27-Oct.10 & 55.1 & 65.7 & 119.1 & 322.6 & 2001 \\
\hline & Chitta & Oct.11-Oct.23 & 36.8 & 72.1 & 196.1 & 601.4 & 1962 \\
\hline & Swati & Oct.24-Nov.5 & 16.8 & 28.9 & 171.7 & 125.1 & 1656 \\
\hline
\end{tabular}


Fig.1 Monthly average rainfall $(\mathrm{mm})$ as recorded at Bidar

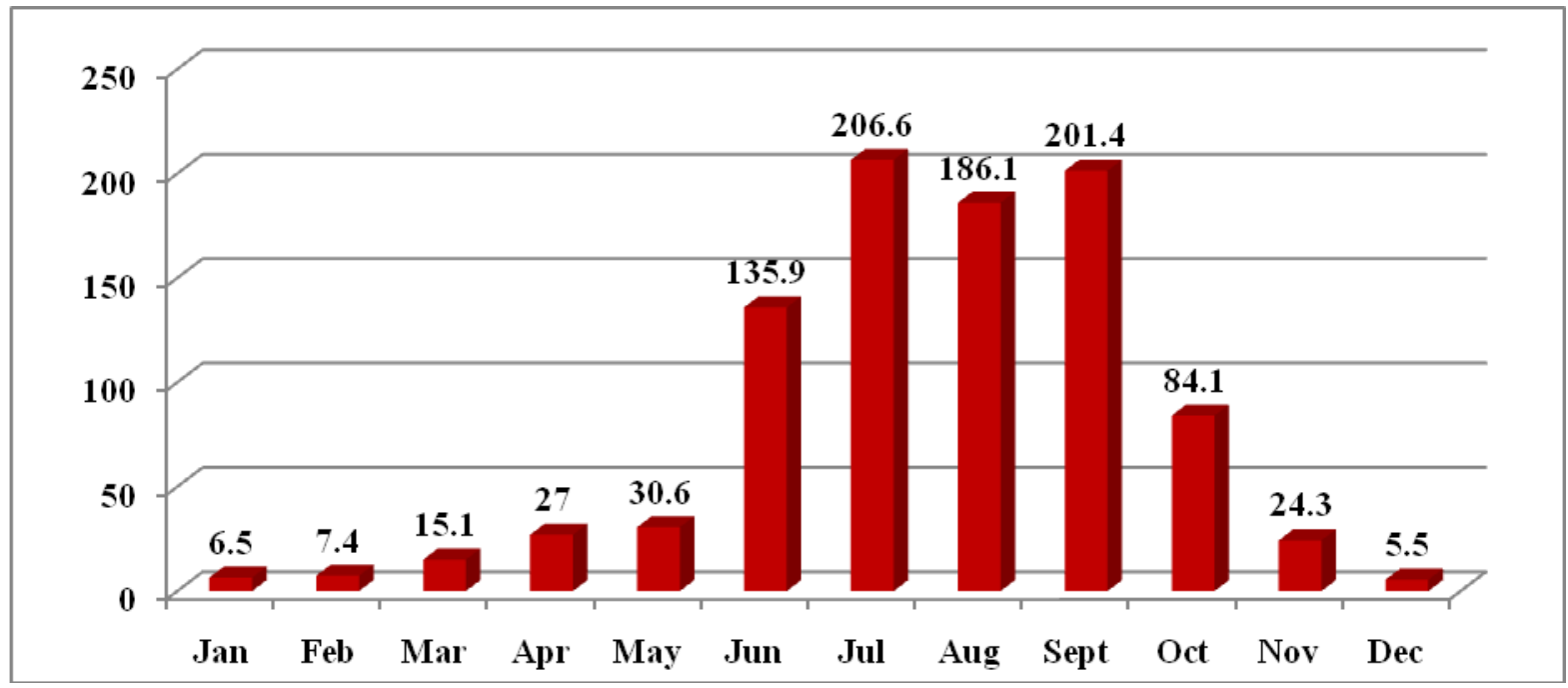

Fig.2 Average season wise rainfall (mm) as observed at Bidar

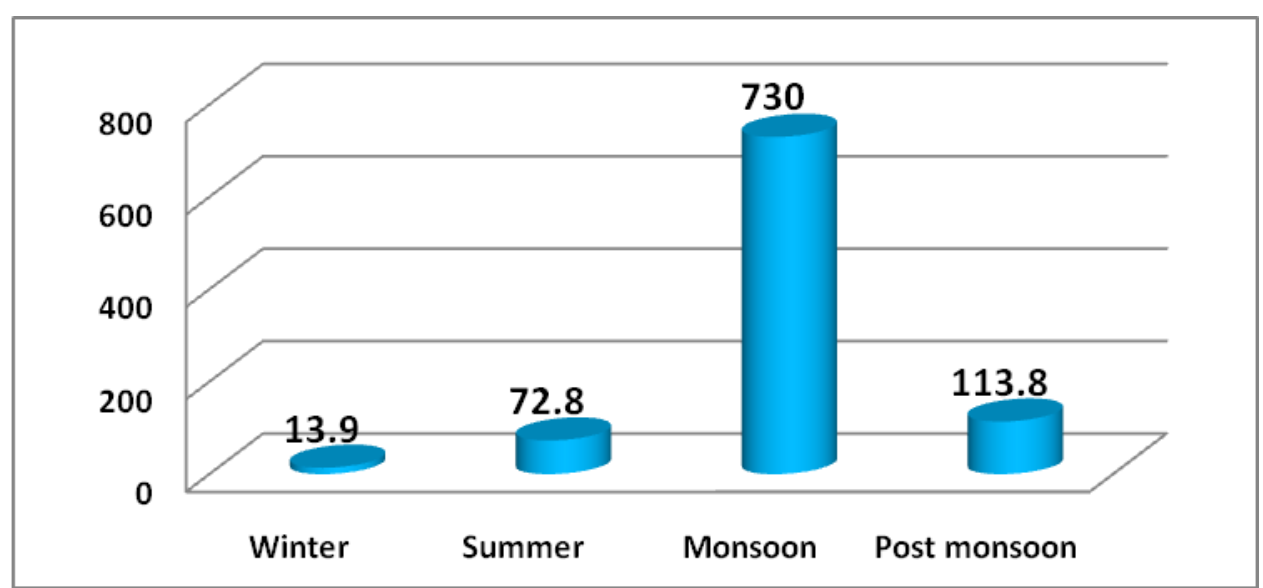

Fig.3 Nakshatra-wise mean rainfall (mm) of Raichur from 1901-2015

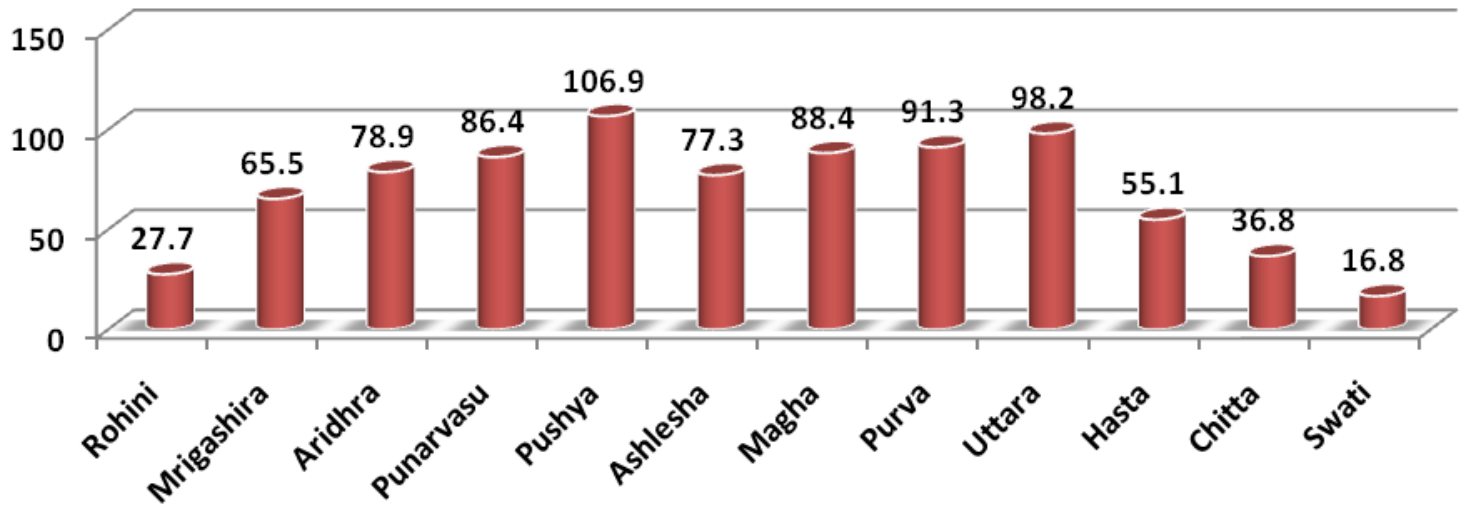


Based on the above analysis, the following recommendations for the region could be made to increase the crop production per unit area under rainfed conditions. About 78.5 per cent of the total average annual rainfall coincides with the monsoon season and is received during a short time span of two to three months between June to September due to south-west monsoon. Rainfall received during summer (March - May) season can be utilized for summer ploughing to make the land ready for final field preparation. With normal onset of rainfall, sowing of main crop like redgram + Jowar, redgram + soybean or sole sugarcane in shallow soils and redgram + blackgram /greengram in medium and deep soils can be taken up. In the event of midseason drought, mulching will be help in reducing soil evaporation and conserving moisture in top layers of the soil. In the event of terminal drought, and under receding soil moisture conditions, crop requires supplementary irrigation.

The major portion of monsoon rainfall is generally lost through runoff which can be stored through the construction of suitable water harvesting structures as on-farm reservoirs which could be utilized for life saving irrigation for rabi crops.

\section{Crop selection for rainfall in different Nakshatra periods}

From the above analysis it is clear that the period from Aridhra to Uttara which covers the monsoon period with adequate amount of rainfall during which crops like greengram, blackgram, soybean, redgram, kharif sorghum, maize, bajra could be grown. With irrigation facility paddy, cotton, sugarcane, chilli can be taken up. The period from Hasta which received good rainfall is suitable for Rabi crops like chickpea sorghum, safflower. The pre-monsoon period like Rohini, received an average of $27.7 \mathrm{~mm}$ rainfall during which land preparation can be taken up.

\section{References}

Bavadekar, V. R., Jadhav, J. D., Mokashi, D. D., Khadtare, S. V. and Kadam, J. R. 2008. Rainfall variation and probabilities in different Nakshatras of drought prone areas, Ag. Update, 3(1\&2): 153-158.

Chabbra, V. and Haris, A. A., 2014. Nakshatra based rainfall analysis and its impact on rabi crops yield for Patna, Bihar, Sch. J. Agric.Vet. Sci.,1(4): 168172.

Chaudhury, J. L. and Tomar, G. S. (1999). Agroclimatic analysis of stable rainfall periods in undivided Bastar district of Chattisgarh region of Madhya Pradesh, India. Oryza, 36(1): 66-69.

De, U. S., Joshi, U.R., and Prakash Rao, G. S., 2004. Nakshatra based rainfall climatology, Mausam, 55(2): 305-312.

Panes, R. S and Sukhatme, P. V., 1985. Statistical methods for agriculture workers. Indian Council of Agricultural Research, New Delhi. 14-33.

Ramana Rao, B. V. (1988). Operational Agricultural Meteorology (problems and priorities). Indian society of Agronomy, IARI, New Delhi.

Sahoo, B. K., Mishra, T. K. and Sahu, P. N. (1991). Rainfall based cropping system in upland conditions of Ganjam, Orissa. Madras Agric. J., 78: 439 - 442.

Sarma, N. N., Paul, S. R. and Sarma, D. (1996). Rainfall pattern and rainfall based cropping system for the hill zone of Assam. Ann. of Agric. Res., 17: 223229.

Sastri, A. S. R. A. S., Rai, S. K., Naidu, D. and Srivastava, A. K. (1999). Influence of climatic parameters on productivity of rainfed rice - a case study of Chattisgarh. Pp 51-61, APC, Publication Pvt. Ltd., New Delhi, India.

Subash, N., Singh, S.S., and Neha Priya., 2011. Nakshatra based rainfall variability, trends and its influences on 
rice wheat production- A case study over two cities in Bihar, India. Journal of Agrometeorology, 13(1): 31-37.

Tiwari, A. K., Sharma, A. K. and Shrivastava, M. M. (1992). Probability analysis of rainfall data of Datia district of Bundelkhand for crop planning. Ind. $J$. Soil Cons., 20 (3): 82-87.

Varshneya, M. C., Vaidya, V. B., Nanaji Kale., and Ketan Kale., 2011.
Performance and evaluation of Saumic Suvrushti project in India, Asian Agri. History, 14(4): 361-372.

Virmani, S. M. (1994). Climate resource characterization in stressed tropical environment: Constraints and opportunities for sustainable agriculture. Pp. 149-160, Oxford and IBH Publishing Co. pvt. Ltd., New Delhi.

\section{How to cite this article:}

Ravi, S., S.N. Bhat, Kamble Anand Shankar and Vishswanath Biradar. 2017. Study of Hundred Years Rainfall Distribution Pattern for Crop Planning in Bidar Region (Karnataka), India. Int.J.Curr.Microbiol.App.Sci. 6(11): 1428-1434. doi: https://doi.org/10.20546/ijcmas.2017.611.170 